$\xi=-1$

\title{
Proposed Corporate Performance Management Using Integrated Performance Management System (IPMS) at PT Pos Indonesia (Persero)
}

\author{
Eliza Prilianti ${ }^{1}$, Muhammad Tresnadi Hikmat ${ }^{2}$ \\ ${ }^{1}$ School of Business and Management, Bandung Institute of Technology, Indonesia \\ ${ }^{2}$ School of Business and Management, Bandung Institute of Technology, Indonesia \\ *Corresponding author E-mail:elizaprilianti@gmail.com
}

\begin{abstract}
The big market shifting in postal industry begun since a physical letter was being substituted by digitalization of technology, yet it brings new business opportunity in the e-commerce industry. The e-commerce industry in Indonesia is expected to grow by approximately $18 \%$ annually in the next five years. It triggers an increasing demand for parcel delivery services. However, the performance of PT Pos Indonesia (Persero) as a State Owned Enterprise engages in postal industry shows the declining trend. The volume of parcel delivery declined during the last three years. The company has not been able to manage its performance due to the incompatibility of performance management system. The purpose of this research is assisting the company to design new performance management system to improve its performance. The Integrated Performance Management System (IPMS) framework is selected because it is able to overcome the issues in the company. There are five stages of IPMS framework includes foundation, background and information, design process, implementation, and refreshment. It consist of three perspectives includes organizational output, internal process, and resources availability. This research proposed the performance management system for Pos Indonesia and produces 20 key performance indicators (KPI) that derived from company's vision, mission, and strategy.
\end{abstract}

Keywords: E-Commerce Industry; Postal Industry; Corporate Performance, Integrated Performance Management System; Key Performance Indicators $(\mathrm{KPI})$.

\section{Introduction}

The big market shifting in postal services begun since the physical letter was being substituted by digitalization of technology. Hartung ${ }^{[9]}$ said that, currently the physical letter is not as valuable as it once was because of the high of customer needs that is to be able to communicate immediately. Moreover, the increasing of internet penetration and mobile device (Smartphone) becomes a part of everyday life, business and governments are shifting to services online ${ }^{[12]}$.

The market shift in postal industry also occurs in Indonesia. The demand shifts from Mail Delivery to Parcel Delivery. Indonesian internet population spends a higher than average amount of time on the internet, especially on social media and online shopping (ecommerce). Revenue of e-commerce in Indonesia amounted to used USD 6 billion. The e-commerce industry is expected to grow by approximately $18 \%$ annually for the next five years, or increase by USD 16,4 billion in the end of 2020 (Das, et al. ${ }^{[8]}$ ).

According to that, PT Pos Indonesia (Persero) called Pos Indonesia as a State Own Enterprise engages in a postal industry begins to transforming its business from Mail Delivery and Financial Service to Parcel Delivery. The transformation aims to reach the company's vision which is "To Be The Logistics Giant From The East." However, since the government issues the new regulation about liberalization in the postal industry, the competition in this industry is getting tighter. The increasing demand for parcel deliv- ery service has stimulated many start-up companies to enter this industry. The situation becomes a great challenge for Pos Indonesia while they attempt to transform its business. Therefore, this research is interesting to be conducted to assist the transformation process of Pos Indonesia.

\section{Business Issue}

The trend of digitalization brings new business opportunities, such as e-commerce that also will have a major impact on other businesses that support it, such as logistics. According to that, the Parcel Delivery Service is predicted to increase. However, in contrast with the market condition, the performance of Pos Indonesia shows the declining trend. In 2016, the revenue growth of the company only increased by $5,16 \%$ while the target is $20,47 \%$. As the highest contribution to the company's revenue, the revenue of Mail and Parcel also did not meet the target, which was only Rp2.692 billion from Rp3.293.

The volume of Parcel delivery declined from 2014 to 2016 . The highest declining occurs in 2015 by $80,7 \%$ and it continued to decline from 4.878 to 4.603 thousand Parcels by 2016. Besides that, the Mail delivery volume also declined from 2013 to 2015. However, in 2016 Mail delivery volume increased due to the significant increased from the Corporate Mail volume that can cover the overall decreasing volume of the Mail delivery. Nonetheless, it also affected by a lack of operational data processing system, where the Parcel delivery less than two kilos falls into the catego- 
ry of Mail delivery while it should be sorted into the category of Parcel delivery.

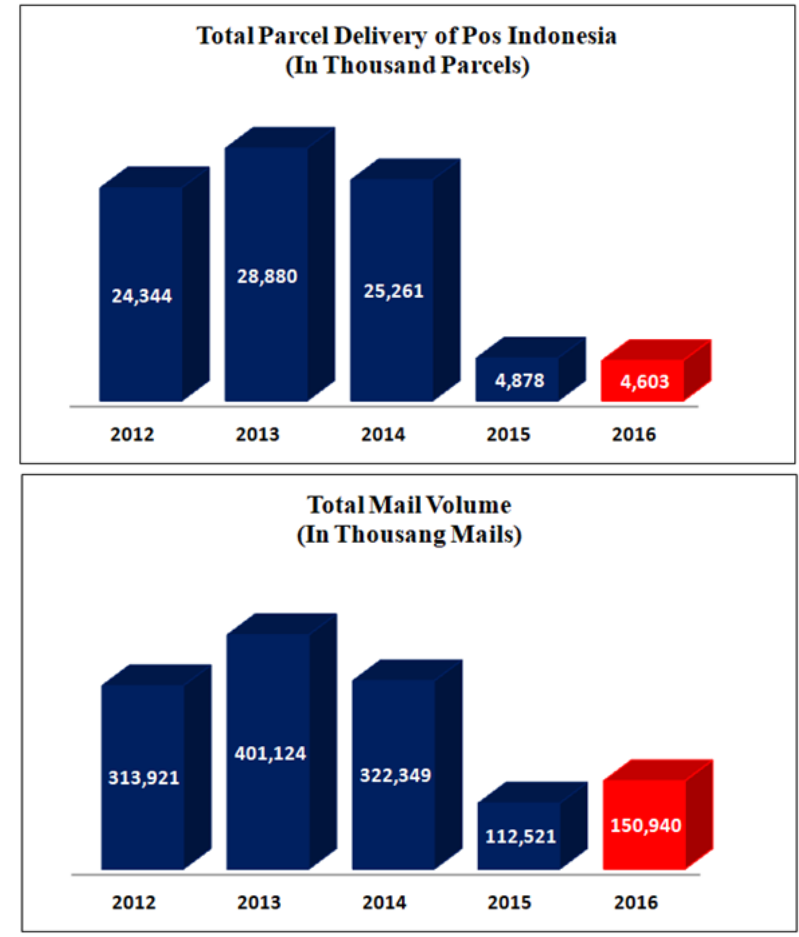

Fig. 1: Productions of mail and parcel during 2012-2016

Moreover, the total score of key performance indicator (KPI) on the KPKU (Kriteria Penialian Kinerja Unggul / Criteria for Superior Performance Assessment) also shows the declining trend from the last five years. The highest declining occur in 2014 by $29,77 \%$. It makes grade of corporate performance decline from Good A-2 to Fair B-3.

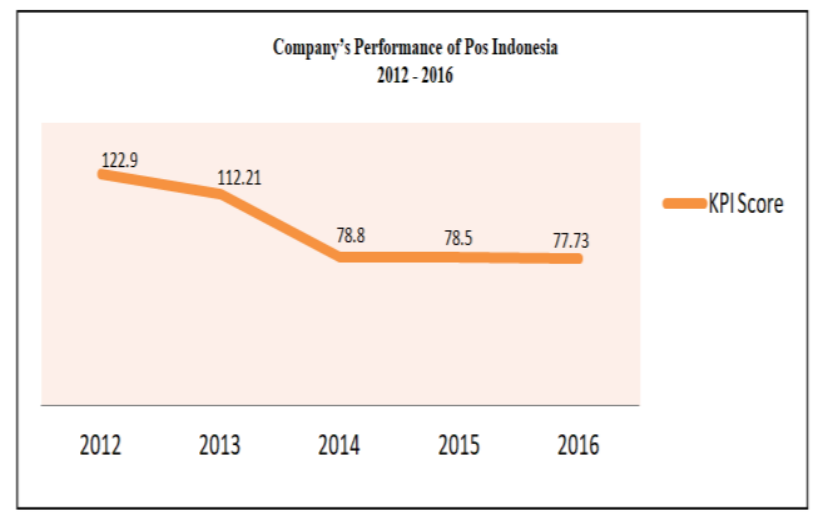

Fig. 2: Company's performance of Pos Indonesia during 2012-2016

In order to assist the company increase its performance, in 2016 the company issued a new corporate performance policy named Business Process Improvement System (BPIS) focuses on three business key driver; revenue, cost reduction, and service. The company also used KPKU as their performance measurement system. It consists of five perspectives, including Finance and Market, Effectiveness of Customer Focus, Effectiveness of Products and Processes, Focus of Employee, and Leadership, Governance, and Corporate Social Responsibility. Besides that, to measure the performance of business and operational business level in the company (called Regional and Technical Implementation Unit Office/UPT Office) the company used SMKU (Sistem Manajemen Kinerja Unggulan / Superior Performance Management System) that consists of eight KPIs include Revenue Growth, EBITDA Margin, Operational Cost Efficiency, Response Time Complaint
Handler (RTCH), Growth Control Of Employee Cost, Investment, Standard Delivery Time, And Service Point.

Although the KPIs of each framework has some similarities, but the KPI of operational management level is not cascaded from the corporate KPI. The SMKU was created separately with the corporate KPI. Therefore, it indicates there is a lack of variable linkage between the Corporate KPI to its business and operational management level. However, there are two critical considerations of performance measurement system; first, the performance measurement system should integrate various areas of the business; second, there should be the deployment of business objectives and policies throughout the hierarchical structure of the organization (Bititci et al. ${ }^{[5]}$ ). Moreover, among the company's level of management there must be a linkage of performance variables that practically, the linkage between performance variables often involves cross-cutting interdepartmental sectors that have authority or levels that sometimes have no vertical relationship (Wibisono $^{[21]}$ ).

\section{Literature Review}

\subsection{Conceptual Framework}

To improve the performance of the company there are several aspects that must be considered. The first is the external and internal environments which are both used as the basic information in order to design the company performance management system. Then, the performance management system will affect to increase the company's performance.

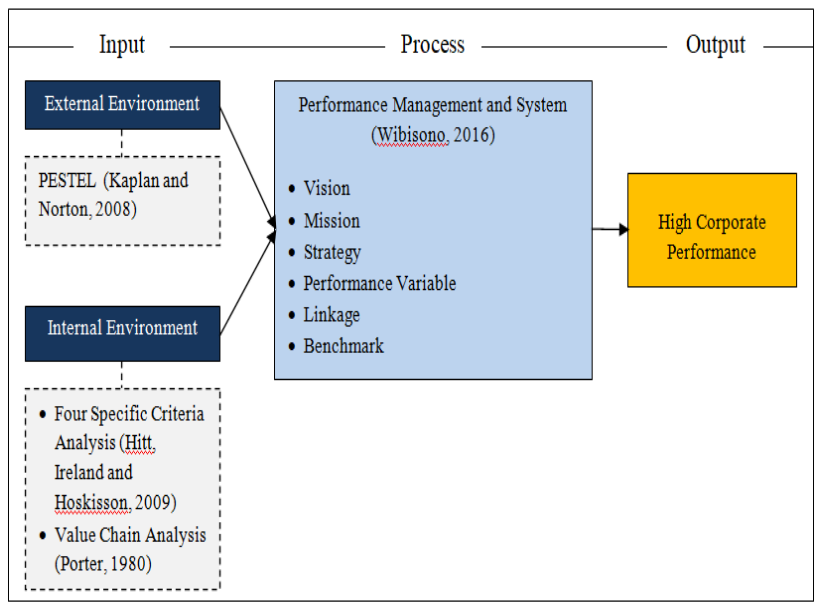

Fig. 3: Conceptual framework

Hitt et al. ${ }^{[10]}$ said that by analyzing the internal and external factors allows the firm to develop the vision, pursue its mission and select and implement its strategies. According to Wheelen et al. ${ }^{[22]}$ the objectives that were established earlier in the strategy formulation part of the strategic management process (dealing with profitability, market share, and cost reduction, among others) should certainly be used to measure corporate performance once the strategies have been implemented.

Wibisono $^{[21]}$ said that the external environment will be related to various policies that must be taken by the company in order to survive and add value in its industry, which then the policy will internally be translated into the programs that must be measured, so that should be accommodated in a performance management system designed. In addition, Anna ${ }^{[3]}$ said that there is a positive significant relationship between management frameworks and techniques utilization to organizational performance. Linkage of other variables in performance management has also been studied to defined the mainstreams in performance management (Hikmat et al. $\left.{ }^{[11]}\right)$. 


\subsection{External and Internal Environment Analysis}

The external environmental conditions is the only thing that company cannot control yet it creates threats to and opportunities for firms that, in turn, have major effects on their strategic actions (Hitt et al. ${ }^{[10]}$ ). The external environment analysis assesses the macroeconomic environment of economic growth, interest rate, currency movements, input factors prices, regulations and general expectation of the corporation's role in society, or it often called PESTEL analysis, reflecting Political, Economic, Social, Technological, Environmental, and Legal.

The external environment also includes industry analysis through Porter's Five Forces analysis in order to calibrate the attractiveness of an industry and aids in identifying specific forces that are shaping the industry, either favorably or unfavorably (Kaplan et al. $\left.{ }^{[15]}\right)$. The Porter's Five Forces consist of Threat of New Entrants, Threat of Substitute Products or Services, Bargaining Power of Buyer, Bargaining Power of Supplier, and Rivalry among Existing Competitors.

However, analyzing the external environment for opportunities and threats is not enough to provide an organization a competitive advantage. It requires internal environment analysis to identify internal strategic factors - critical strengths and weaknesses that are likely to determine whether a firm will be able to take advantage of opportunities while avoiding threats (Wheelen et al. ${ }^{[22]}$ ). There are two frameworks that used to identify opportunities and strengths of the company include the value chain analysis and four specific criteria of sustainable competitive advantage. The value chain analysis identifies the sequence of processes necessary to deliver a company's products and services to customer and also help the company to identify the business activities that it intends to perform differently or better than competitors to establish a sustainable competitive advantage (Kaplan et al. ${ }^{[15]}$ ). Besides that, the four specific criteria of sustainable competitive advantage used to determine the core competencies of company's capabilities (Hitt et al. ${ }^{[10]}$ ).

\subsection{Corporate Performance and Management System}

According to Wheelen et al. ${ }^{[22]}$, performance is the end result of activity. In addition, Wibisono ${ }^{[21]}$ said that the result is only known through the measurable thing. Therefore, as mentioned before that corporate performance has the close relationship toward performance management system.

Aguinis $^{[1]}$ said performance management system is a continuous process of identifying, measuring, and developing the performance of individuals and teams and aligning performance with the strategic goals of the organization. Moreover, Smither et al. ${ }^{[20]}$ said that performance management consists of a number of processes dealing with communicating expectations about individual performance, assessing performance through quantitative ratings or qualitative narratives, and providing feedback for administrative or developmental purposes, among other things. According to that, the performance management cannot stand alone without the measurement. So, it can be said that performance management and measurement system is a set of frameworks as the continuous process within the organization in order to improve its performance.

Wibisono $^{[21]}$ said that the framework of designing the performance management system consists of determining the vision, mission, strategy, and framework chosen as the basis for determining the performance variables, the interrelationships between the variables, and the benchmarks to be taken. According to Soo ${ }^{[19]}$, the vision describes where the organization is headed and what it intends to be. Pearce ${ }^{[17]}$ said that the mission is a statement of purpose that distinguishes a business from other firms of its type and identifies the scope of its operations in product and market terms, it not also embody the strategic decision makers' business philosophy, but reveals the image the company seeks to project, reflect the firm's self-concept, and indicates the principal product or service areas and the primary customer needs the company will attempt to satisfy. Hitt et al. ${ }^{[10]}$ said that a strategy is an integrated and coordinated set of commitments and actions designed to exploit core competencies and gain a competitive advantage.

According to Wibisono ${ }^{[21]}$, the most important aspect in designing performance variables is a balanced amount of performance variables that indicate past, present and future performance. Past performance or called lagging metrics provide results data that have occurred while the present performance shows the performance that is currently happening in a short period, so, it provides the improvement if the performance does not meet the target. Besides that, there must be a linkage between the variables in order to identify the area that need to be improved. Moreover, benchmarking also used to improve performance by understanding the methods and practices required to achieve world - class performance levels (Isoraite, ${ }^{[13]}$ ). Through that, the companies can see the other side out of the business process that currently applied, so it will generate the new ideas that are quite revolutionary (Wibisono ${ }^{[21]}$ ).

\subsection{Business Issue and Root Cause Analysis}

In the middle of the increasing e-commerce industry, Pos Indonesia has not been able to show its competitiveness to compete with its competitors. The company admits that the business strategy in 2016 has not been fully able to deal with the market condition. Such as the business of Mail and Parcel strategy that still refers to the business and operational mail, while the existing market demand shows that the business orientation shift to the Parcel Delivery both in terms of infrastructure, resources, and facilities. The company also only focuses on network exploitation rather than people and technology. The company realizes that the parcel delivery service not become the first choice for online consumers in Indonesia.

According to Gilarsi as the CEO of Pos Indonesia, the brand image of Pos Indonesia is better known with the physical mail and remittance, while the Parcel delivery shifted towards new players (Dalimunthe ${ }^{[7]}$ ). Moreover, the users of the parcel delivery services mentioned that Pos Indonesia is considered have a lack of brand image and service quality when compared to other parcel delivery service providers (Afiani et al. ${ }^{[2]}$ ). Besides that, compared with the competitors, the company provides longer delivery time (Exhibit 8).

In addition, to manage its performance, Pos Indonesia used various kinds of performance measurement system which is each of it standalone represents each area of the company (Table 1). According to Bititci et al ${ }^{[5]}$, the performance management system should enable the correct deployment of the strategic and tactical objectives of the business as well as providing a structured framework to allow the relevant information to feed back to the appropriate points to facilitate the decision and control processes. Niven ${ }^{[16]}$ also said that in order to pursue the strategic objective of the company, the measures should link together in a chain of cause and effect relationship, so they can be monitored, managed, and validated. Moreover, Wibisono ${ }^{[21]}$ said companies that implement multiple performance measurement frameworks separately, without synergy and integration of the various systems implemented, there will be overlaps between the implementation and design, as well as adding the workload due to redundancy.

Thus, the root cause of the issues that occur is the incompatibility of performance management system currently applied by Pos Indonesia. According to that, the company needs to improve the performance measurement system that can accommodate the company to achieve its goal. 
Table 1: Current performance measurement frameworks at Pos Indonesia

\begin{tabular}{|c|c|c|c|}
\hline Criteria & BPIS & KPKU & SMKU \\
\hline KPI & $\begin{array}{l}\text { - Revenue, } \\
\text { - Cost Control, } \\
\text { - Services. }\end{array}$ & $\begin{array}{l}\text { - Finance and Market, } \\
\text { - Effectiveness of Customer } \\
\text { Focus, } \\
\text { - Effectiveness of Products } \\
\text { and Processes, } \\
\text { - Focus of Employee, } \\
\text { - Leadership, Governance, } \\
\text { and Corporate Social Re- } \\
\text { sponsibility. }\end{array}$ & $\begin{array}{l}\text { - Revenue growth, } \\
\text { - EBITDA margin, } \\
\text { - Operational cost efficiency, } \\
\text { - Response time complaint handler } \\
\text { (RTCH), } \\
\text { - Growth control of employee cost, } \\
\text { - Investment, } \\
\text { - Standard delivery time, } \\
\text { - Service point. }\end{array}$ \\
\hline Function & $\begin{array}{l}\text { Measure the corporate perfor- } \\
\text { mance, used as the internal infor- } \\
\text { mation to make decision. }\end{array}$ & $\begin{array}{l}\text { Measure the corporate perfor- } \\
\text { mance, used for external stake- } \\
\text { holders (government). }\end{array}$ & $\begin{array}{l}\text { Measure the Regional and UPT Office } \\
\text { performance, used as the internal infor- } \\
\text { mation to make decision. }\end{array}$ \\
\hline $\begin{array}{l}\text { Cascaded to different level of } \\
\text { management }\end{array}$ & No & Only to Board of Director & No \\
\hline $\begin{array}{l}\text { Relationship between variables at } \\
\text { different levels of management }\end{array}$ & No & No & No \\
\hline
\end{tabular}

Bititci et al. ${ }^{[6]}$ said there is former research that proves that the performance management and measurement system affect the company's performance if it managed using formalized, balanced and integrated performance measures. Therefore, improving the company performance measurement system should be part of the transformation step to achieve the company's vision being the giant postal logistic from the east.

\section{Research Methodology}

The problem identification of this research is the declining performance of Pos Indonesia. The objective of the research is designing the corporate performance management system for Pos Indonesia by using Integrated Performance Management System (IPMS) framework (Wibisono ${ }^{[21]}$ ). This research is using a qualitative method. The data was collected from primary and secondary data. Deep interview with several the company officer is used as the primary data while company's past document, literature study, internet and newspaper is used for the secondary data. The designing performance management system was conducted once the analysis of the alternative solution has been done in order to get the best framework that fit into the business process of the company.

Table 2: Comparison between the performance management frameworks

\begin{tabular}{|c|c|c|c|}
\hline Criteria & BSC & Performance Prism & IPMS \\
\hline Design procedure PMS & Clearly stated & General overview & Clearly stated \\
\hline Perspective & 4 Perspectives & 5 Perspectives & 3 Perspectives \\
\hline Number of suggested variables & $\begin{array}{l}\text { Grouped in } 4 \text { major perspectives each } \\
\text { perspective can contain several varia- } \\
\text { bles depending on the managed com- } \\
\text { pany }\end{array}$ & $\begin{array}{l}\text { More than } 200 \text { individual per- } \\
\text { spectives }\end{array}$ & $\begin{array}{l}\text { Grouped in } 3 \text { major perspectives each } \\
\text { perspective can contain several varia- } \\
\text { bles depending on the managed com- } \\
\text { pany that has inter-correlated between } \\
\text { each variables }\end{array}$ \\
\hline $\begin{array}{l}\text { Methods of relationship assess- } \\
\text { ment and improvement priorities }\end{array}$ & Not given & Not given & Clearly given \\
\hline Output & Financial output & Stakeholder satisfaction & Financial and nonfinancial output \\
\hline
\end{tabular}
Source: Wibisono ${ }^{[21]}$

There are some advantages by using IPMS (Wibisono ${ }^{[21]}$ ):

A. Provides simple and structured approach focuses on process and performance result,

B. Assist stakeholders to determine strategy, targets, and evaluate the result together,

C. Provide the potential system to measure the performance fairly in determining the roles, responsibilities, and rewards,

D. An excellent framework in terms of accountability determination,

E. Divides responsibility to the parties involved to improve performance.

\section{Business Solution Analysis}

The root cause that makes the performance of Pos Indonesia declined is the inadequate performance management system. The company used various kinds of measurement system to measure some area of its company. Moreover, the measurement system is not cascaded into all management level of the company. It makes the measurement system of the company has lack of relationship variables with each management level of company. In addition, the current measurement system also has not equipped yet with relationship assessment method. In other words, the company's measurement system still cannot meet the needs to improve its performance. Wibisono ${ }^{[21]}$ said that the linkage between performance variables is very important in performance management because it will facilitate the process improvement that must be done on performance variables that do not reach the target.

There are many performance management system that can be adopt by the companies in order to improve the company's performance, such as Balanced Scorecard, Performance Prism, and Integrative Performance Measurement System. Table 2 describes comparison between each performance management frameworks. 
The basic information needed as input for the design of performance management system is basically concerning the business environment that is currently being cultivated consists of information about the industry, government, and society, market, and competitors as well as products and services produced by the company.

\section{Stage 2: Design}

The steps of designing a performance management system consisting of determining the vision, mission, strategy, and framework are chosen as the basis for determining the performance variables, the interrelationships between the variables, and the benchmark to be taken.

D. Stage 3: Implementation

The third stage includes the display to be supported, the report to be designed, the socialization of the performance management system to all employees, the benefit or cost analysis for the implementation of the performance management system, the modification of the process if necessary, the training to be included, the resources to be involved in the implementation and the position of the current performance management system to the new performance management system. At the time of implementation, it should be tested whether the performance management system has been able to accommodate four key areas of measurement, evaluation, diagnosis and follow-up required if there is a gap between the corporate performance and the target.

E. Stage 4: Refreshment

An evaluation step towards the current performance management system's performance is designed with consideration of current information and knowledge developments.

\section{Designing an Integration Performance Management}

\subsection{Stage 0: Foundation}

According to Wibisono ${ }^{[21]}$, in developing a performance management system there are four foundations and five rules as guiding principles that need to be considered. The four foundations include:

A. Stakeholders' partnership. Pos Indonesia should make the partnership with all stakeholders involved such as management, employees, customer, and supplier to gain the understanding and commitment from them in way to achieve the objective of the change itself.

B. Employees' empowerment. All the leaders of Pos Indonesia must be able to empower their employees to play a role in improving the company's performance in-line with the performance management system that has been set into their work unit.

C. Integrated performance improvement. The framework management system should have a variable linkage between each department in order to increase sense of belonging between each other.

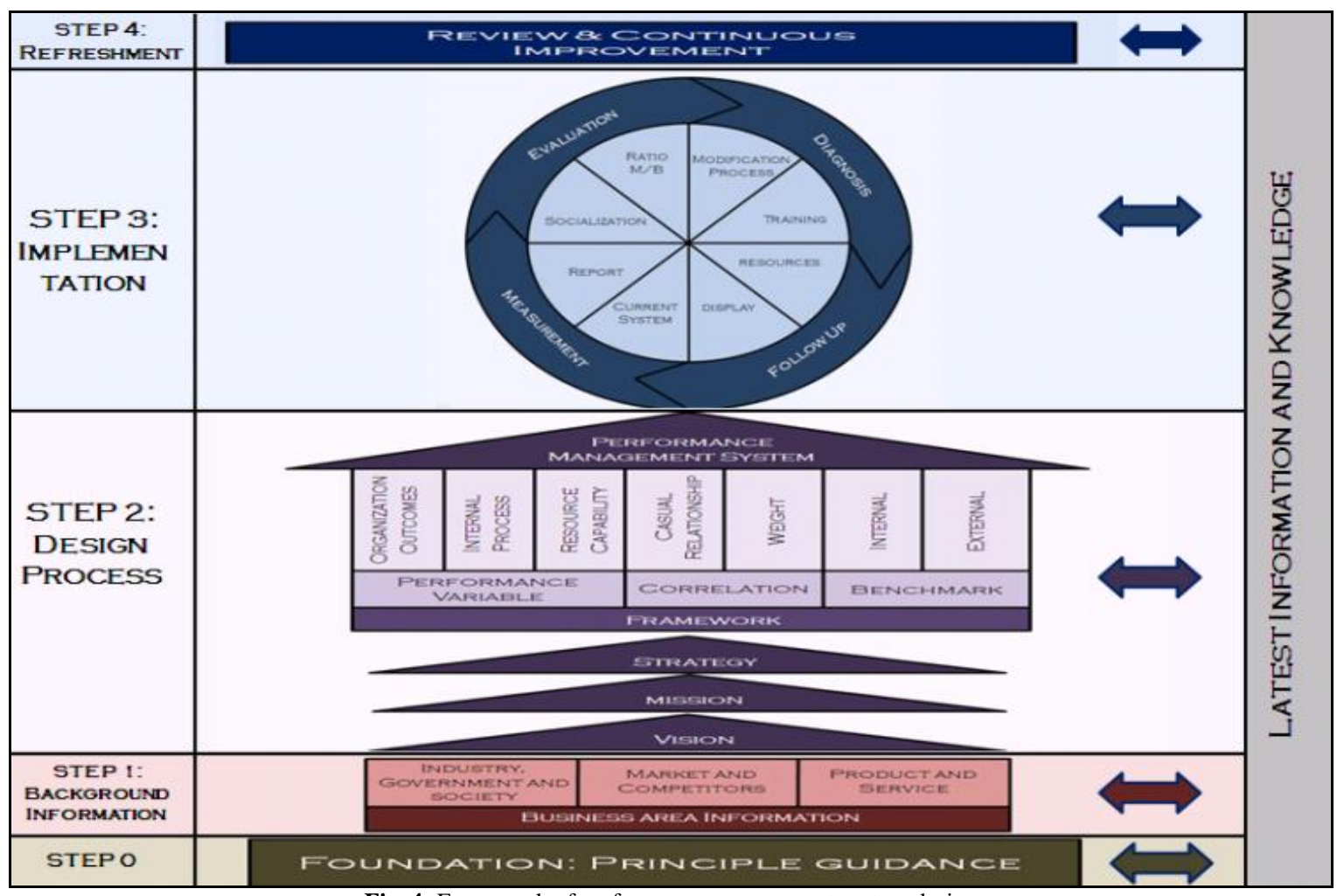

Source: Wibisono ${ }^{[21]}$

Fig. 4: Framework of performance management system design

D. Independent Team. Pos Indonesia should be able to give the opportunity and trust to performance management development team. They must be given an authority to take the decision include organize the employees and establish the variable that should be apply in every department. They also should be supported by all of employees and management within the company.

Meanwhile, the five rules that also need to be considered consists of:
A. Easy to understand. Pos Indonesia should develop the performance management system that easy to understand and implemented, so they can focus to improve their performance.

B. Long-term orientation. The performance management system of Pos Indonesia should consist of two aspects which are financial and of nonfinancial aspect in order to have a long-term sustainability.

C. Time based. The performance management system at the operational level of Pos Indonesia should use real-time based varia- 
bles to provide a feedback to enable the company immediately follow up the target that cannot be achieved.

D. Focus on continuous improvement. In order to focus on continuous improvement, Pos Indonesia should implement the benchmark both in internal and external benchmarking.

E. Using quantitative approach. The performance management system that will be implemented in Pos Indonesia should use quantitative approach so it is easy to be followed up.

\subsection{Stage 1: Background Information}

\subsubsection{PESTEL Analysis}

PESTEL analysis consist of six aspects, there are:

A. Political

The existence of regulatory changes in UU No. 38/2009 provides flexibility for post operators in the form of opportunities to regional-owned enterprises, private entities, and cooperatives to conduct postal activities in Indonesia. So there will be a change in the business ecosystem, including the development of information technology and telecommunications, and the emergence of many competitors. However, Indonesia's government launched the Economic Package XIV that consists of e-commerce's roadmap to enhance the economy of Indonesian society. According to that, the government decided Pos Indonesia to become the e-commerce platform of the national logistics sector and the company is expected to become a national logistic platform.

B. Economic

Indonesia's economic condition grew to $5.02 \%$ in 2016 from $4.9 \%$ in 2015. By 2017, the growth of real GDP is projected to increase become $5.2 \%$, and reach $5.3 \%$ in 2018. Meanwhile, the increasing real wages and declining unemployment rates support for increased consumer purchasing power. In addition, the e-commerce industry is expected to continue to develop and support the Indonesian economy. In the last 10 years, the e-commerce industry in Indonesia has grown by around $17 \%$ with a total of 26.2 million businesses. Das et al. ${ }^{[8]}$ said that the switch to the digital business will boost economic growth to $\$ 150$ billion by 2025 . It will make Indonesia as a largest e-commerce growth country in the world The logistic industry in Indonesia is also predicted to growth until 2020 and reach $15,4 \%$ or Rp 4.396 trillion.

C. Social

Total population of Indonesia in 2016 is 256,2 million $^{[4]}$. The population of Indonesia is projected to grow to 271,1 million in 2020 and continue to growth become 305,6 million by 2035 . Currently, Indonesia is in the period of demographic bonus, the population of productive age is more than young and old age. According to Razdan et al. ${ }^{[18]}$, Indonesian's consuming class is expected to grow significantly in 2020 to be 86 million people. It increases by $7 \%$ compared to 2013 which is 55 million. Besides that, along with the increasing internet penetration in Indonesia, by $78 \%$ of the internet user population in Indonesia is engage in the ecommerce activity. It shows that Indonesia has high potential in the e-commerce business sector that gives the opportunity to the courier and logistic industry.

D. Technology

The existence of digitalization trend has been able to change people's lifestyles. The emergence of e-commerce in Indonesia also changed the business of Pos Indonesia. Through the e-commerce, online shopping increase, the growth of parcel business also continues to increase. It is in contrast with the mail delivery that decline because it is no longer meet the market demand. In other words, digitalization trend can still be utilized by Pos Indonesia, especially in courier service, because parcel delivery is nonsubstitutable.

E. Environment

As an archipelagic country, every island in Indonesia has different natural resources with each other, causing interdependence between islands in Indonesia in fulfilling its needs. This is also driv- en by differences in production capability, as well as differences in purchasing power and consumption in each island, causing the need for transportation between the islands. The high demand for logistics services in Java and Sumatera make many logistics players concentrating their efforts on both islands, causing intense competition. While the main flow of goods between islands in Indonesia is in Sumatra-Java-Bali. More than half the volume of inter-island transport takes place between the three islands.

F. Legal

As a State-Owned Enterprise in the form of Limited Liability Company, PT Pos Indonesia (Persero) follows the UU Number 40/2007 regarding Limited Liability Company. In addition, the existence of PT Pos Indonesia (Persero) as a state-owned enterprise engaged in business services of Mail, Logistics and Financial services are also subject to various laws and regulations as follows:

a) UU Number $19 / 2003$ according to SOE;

b) UU Number $38 / 2009$ according to Posts;

c) Government Regulation Number 15/2013 according to the Implementation of Law Number 38/2009 regarding Post.

According to UU number $38 / 2009$ and Government Regulation No. $15 / 2013$ that in its implementation, the government contributed to managing the business process of Pos Indonesia to improve and develop its services.

\subsubsection{Porter's Five Forces Analysis}

The five aspects of the porter's analysis are:

A. Threat of new entrants: high

Threat of New Entrants is high since the government makes a new regulation regarding postal industry, UU No. 38/2009. The companies who engage in courier service continue to grow. Especially after the tech-based company also started to enter into the courier and logistics industry like Gojek with GoSend, and Grab with Grab Delivery makes the competition is getting tighter. The new entrant also come with a variety of innovations, such as one of the new comers, namely J\&T offering similar service with Gojek or Grab, direct pick up to the customers' house who wants to send the parcel to the intended recipient.

B. Threat of substitute product: low

The threat of substitute product is low because there is no substitute product or services for the parcel delivery.

C. Bargaining power of buyer: high

The number of players in the courier service industry makes customers compare the services offered from one company to another to meet their needs. Surely the customers want a courier service that can provide the best service; save, fast and cheap. The price of delivery service also becomes an important thing especially for the online shopping buyers because it will affect the price of the product that they buy. Moreover, the customer in this industry also very price sensitive.

D. Bargaining power of suppliers: moderate

In 2012, Pos Indonesia established the logistic company called Pos Logistic. All the supply chain activities include warehousing, freight forwarding, transporting and supply chain solution are executed by Pos Logistic. Therefore, it gives the ease for Pos Indonesia in order to operating its mail and parcel service. The company also cooperate with some transportation companies in order to expand their shipping route include PT Garuda Indonesia, PT KAI, PT Pelni, and many others. Mostly, the supplier group not takes the major revenue from this industry. Generally, the bargaining power of the supplier is moderate since the suppliers have the power to determine the schedule, there are also just a few suppliers who served different route, there are many substitute suppliers, and low switching cost.

E. Intensity of rivalry among competitors: high

The tight competition in the courier industry makes the intensity of rivalry among competitors is high. The growing number of newcomers by offering innovative products at competitive prices 
is the main factor. So it triggers the courier service companies in the industry to actively give the promotion. The strong intensity of the rivalry not only shown by their strategic competition but also the shipping price that they offer is very competitive.

\subsubsection{Value Chain Analysis}

The focus of value-chain analysis is to examine the corporation in the context of the overall chain of value-creating activities, of which the firm may be only a small part (Wheelen et al. ${ }^{[22]}$ ). The value chain analysis of Pos Indonesia is briefly described in Exhibit 1.

\subsubsection{Four Specific Criteria for Sustainable Advantage}

Four specific criteria analysis is conducted to find the strength or core competency of Pos Indonesia. The capabilities are taken from the value chain analysis of Pos Indonesia that describe earlier. From the four specific criteria analysis (Exhibit 2), it can be concluded that Pos Indonesia has two sustainable competitive advantages, including government support and provide cheapest price for standard delivery service by using price based on actual weight (no rounding weight) strategy.

\subsubsection{SWOT TOWS Analysis}

Based on external and internal analysis, the strengths, weaknesses, opportunities and threats of Pos Indonesia are described in Exhibit 3 . Then after analyzing strengths, weaknesses, threats, and opportunities, the next step is conducting TOWS matrix analysis. The purpose is to design company's strategies in order to take advantage of opportunities and minimize threats by harnessing strengths and overcoming weaknesses.

\subsection{Stage 2: Design Process}

\subsubsection{Vision, Mission, and Company's Strategy}

The vision of Pos Indonesia is to be the giant postal logistics from the east. Meanwhile the mission of the company is to be a valuable asset for the nation and its people, to be a joyful place of work, to be the best choice for the customers, constantly striving to provide a better service for the nation, its people, our customers, employees, the society and shareholders. Based on the current strategy, Pos Indonesia is realized that the tight competition of Postal industry insist them to improve their business by developing their product or service in order to create value. In addition, Pos Indonesia is also aware that its shortcomings will have an impact on the process of achieving its vision. Therefore, besides focusing on value creation, the company also focuses on upgrading the company's resources.

Furthermore, In order to help achieve its vision, strategic steps that must be done by Pos Indonesia is described in Figure 5. To improve its current strategy, the strategic map created is a combination of Pos Indonesia strategy and TOWS analysis. The strategic map that created divided into three perspectives includes organizational output, internal business process, and resource availability.

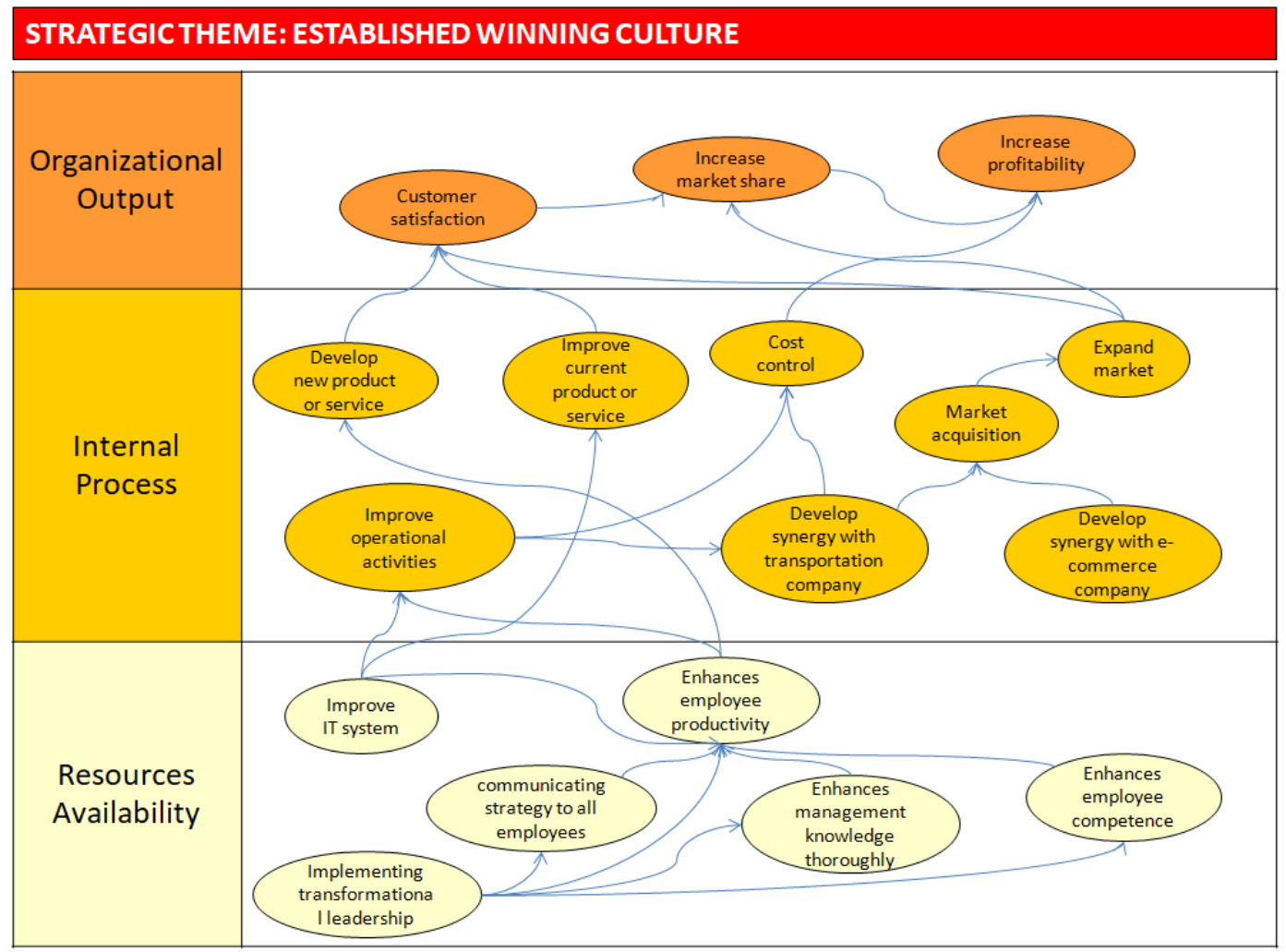

Fig. 5: Strategic map

\subsubsection{Performance Variable}

The performance variable of the IPMS consists of three perspectives with some variables that measured by several key performance indicator. The first is perspective of organizational output that consists of two variables, financial and non-financial output (Exhibit 4). Both aspects have the same level of importance to evaluate company performance. It because basically, both aspects managed to meet the various needs of stakeholders.

Furthermore, the indicator that used to measure the financial and non-financial output in Pos Indonesia is described below:

A. Financial Output

a) Profit growth 
This indicator used to measure the profit growth of the company compared to the previous year. This indicator gives the investor an idea of the company's ability to generate or increase profits.

b) EBITDA margin

This indicator used to measure the company's operating profitability as the percentage of its revenue. The higher EBITDA margin implies that the company has smaller operating expenses. So, this indicator also can be used to measure the company's efficiency.

c) Asset growth

This indicator used to measure the growth of the company's assets compared to the previous year. The growth of company's assets can increase the value of the company especially if it used maximally to generate revenue or profit. Thus, asset growth gives investors an idea of the company value.

d) Asset turnover

This indicator used to measure the efficiency of Pos Indonesia uses its assets to generate sales. The higher value of the company's asset turnover indicates that the more efficiently its assets have been used. This indicator gives investor idea of how the business operational process of Pos Indonesia has been financially efficient.

e) Market share

This indicator refers to the percentage of market that captured by Pos Indonesia. It used to measure the company's size within its market.

\section{B. Non-financial output}

Customer satisfaction is used as the indicator to measure the nonfinancial output. This indicator is used to control the level of customer satisfaction by the service provided. It measured by the total number of customer complaints in the certain period. It gives an idea of the service quality provided toward the customer expectation. Since Pos Indonesia not only provide services to the individual community but also to the institution or company to help facilitate the delivery of mail or parcels, so the indicator that used to measure the customer satisfaction divided into two types which are corporate customer satisfaction and individual customer satisfaction.

The second is internal process which consists of four aspects include innovation, operation, marketing, and after sales service (Exhibit 5). Internal process will give the positive contribution to the organizational output both in financial and non-financial output if it managed properly.

Since Pos Indonesia still concern to develop its business, so the innovation activities of the company related to the investment activities such as develop existing product, develop new product, develop internal data system, and technology development. Therefore, work program realization and physical program realization is used to measure the innovation aspect. Both indicators used to measure the level of the investment plan program and budget plan. Besides that, the operating process consists of two KPIs, operational cost and standard delivery time. Operational cost used to measure the cost efficiency of the operational business activity. It will give an idea how Pos Indonesia can manage its cost in order to generate profit. While standard delivery time used to improve delivery performance which expected gives positive impact to the brand image of Pos Indonesia.

Moreover, e-commerce penetration and number of network is used as the KPI of marketing aspect. E-commerce penetration used to measure growth of e-commerce penetration of the company. It will give the investor an idea of the company's ability to increase the market share in the e-commerce channel market. While the number of network used to measure the total network of the company. The objective of this indicator is to increase the number of network to provide vast network within Indonesia and achieve the company vision to be the backbone of e-commerce logistic.

Besides that, the KPI to measure after sales service is respond time to complain handling. This KPI is very important because it will affect the level of customer satisfaction to the services provided by Pos Indonesia. For the company, this indicator can assist the company in evaluating whether the service provided by the company has fulfilled customer needs.

The last perspective is resources availability that consist of three aspect measurement include human resources, technology, and organization (Exhibit 6). According to Wibisono ${ }^{[21]}$, nowadays almost all companies in the world are trying to build different and sustainable values by increasing intangible assets such as human resources, technology, and the organization. Moreover, he said that based on former research, $75 \%$ intangible assets can generate added value for the company. Therefore, these three components are important to be managed in line with the company's strategy so the company has the ability to improve its business process needed in implementing the strategy.

Therefore, there are several indicators to measure the resource availability in Pos Indonesia that describe below.

A. Human resource

a) Employee engagement index

This indicator used to measure the employee engagement emotionally and intellectually for the success of the company. Employee engagement levels include employee engagement to help achieve the company's strategic goals such as improving corporate reputation, corporate strategy, creating working conditions, achieving performance targets, and developing human resources.

b) Employee productivity

This indicator used to measure the revenue of employees generated in the company's business activities. It also used to measure the level of employee contribution to the company and identifies the efficiency and effectiveness of a company.

c) Employee satisfaction

This indicator used to measure the level of employee satisfaction in Pos Indonesia. It is important to be evaluated because it will give the positive contribution to the company's performance.

B. Technology

The KPI that used to measure the technology is network availability. This indicator used to measure the readiness and availability network of Pos Indonesia in order to increase the operational activities. The network availability is one of the most important resources that should be developed to give the competitiveness and to pursue the company's vision.

C. Organizational resource

a) GCG index

GCG is the acronym for Good Corporate Governance. This indicator used to measure the GCG implementation by Pos Indonesia. The purpose is to monitor and evaluate the corporate governance in order to maintain the quality of its implementation and to keep aligned with the development of applicable laws and regulations. In order to conducting the sustainable business align with its business activities, Pos Indonesia is committed to increase the awareness of GCG, doing continuous improvement, and also make those as part of corporate culture in the implementation of GCG.

b) PSO implementation

As one of the companies who granted compensation by the government, this indicator used to evaluate how Pos Indonesia utilizes the government compensation in order to expand the network to rural area.

\subsubsection{Linkage Variable}

Linkage variable is the important thing for corporate management. It can help the company to determine the area of the company that need to be improved. However, due to some confidential data, so the linkage variable is obtained from focus group discussion (FGD) with several managers in Pos Indonesia. To obtain the causal relationship between the variables, the linkage variable used the fishbone diagram method. Fishbone diagram is a tool to show the hypothesized relationship between potential causes and the problem (Jacobs et al. ${ }^{[14]}$ ).

Exhibit 7 shows the variable linkage of Pos Indonesia. The red color of each KPI refers to the variable that has less relationship. 
From the linkage variable, it shows that the indicator of Employee Engagement Index, Employee Productivity, Employee Satisfaction, PSO Implementation has less relationship with Work Program Realization and Physical Program Realization. It because based on FGD, the Work Program Realization and Physical Program Realization is executed by sub-contractor or supplier and there is also only several internal departments and PSO project who related with this indicator.

\subsubsection{Benchmarking}

The objective of the benchmark that conducted is to know the performance of the company in terms of the service provided by Pos Indonesia compared to its direct competitor, so the benchmarking method used is performance benchmarking. From several competitors, the most appropriate competitor is PT Tiki Jalur Nugraha Eka Kurir (JNE) because they received the award as the Best Consumer Delivery Service Company from Indonesia ECommerce Award (iDEA).

From the benchmarking analysis, it can be concluded that based on the price, Pos Indonesia offers cheaper price than JNE for Standard Parcel delivery. However, for other types of delivery, Pos Indonesia offers more expensive prices in the Java Island area and the prices are relatively similar for destination Bandung Pangkal Pinang (Bengkulu), Bandung - Pontianak (West Kalimantan), Bandung - Makassar (South Sulawesi), Bandung - North Jayapura (Papua). Meanwhile, when compared to standard delivery time, JNE is faster than Pos Indonesia. The table of benchmarking analysis is shown on Exhibit 8.

\subsection{Stage 3: Implementation}

The implementation of IPMS framework should considering several aspects there are current performance management system, reporting system such as reports or documents that needed, socialization process to inform the new change to entire level of company, cost ratio benefit analysis, training, resource allocation to implement the IPMS framework, and display that used as a tool to monitor, control, evaluate the company performance. Regarding the reporting system and the resource allocation, Exhibit 9 describes both aspects in order to implement the new performance management system in Pos Indonesia.

\subsection{Stage 4: Refreshment - Maintenance and Update}

The last stage of the IPMS is the refreshment. It means that performance management system that implemented need to be updated and followed the trend within the industry, market, technology, customer needs, as well as the evolution of performance standards and the latest method. Besides that, the company also needs to maintain the several aspects include leadership, commitment, and stakeholder contribution to keep their spirit in executing the performance management system.

\section{Conclusion}

The Integrated Performance Management System (IPMS) framework is selected to be the most suitable framework for Pos Indonesia. The IPMS framework is chosen because the framework is able to overcome the issues that occur in the company. It is not only provides the relationship between the variables but also the methods of relationship assessment and improvement priorities. So, IPMS can help Pos Indonesia to find what area the need to be improved to increase the company performance. Besides that, the IPMS framework also able to translate the company's vision into the lower management level of the company that make all the business activities align with the company's objective. As the result, this proposed performance management system of Pos
Indonesia produce $20 \mathrm{key}$ performance indicators (KPI) which derived from the vision, mission, and the strategy of the company. Furthermore, Exhibit 10 and Exhibit 11 show the comparison between before and after implementing IPMS by using four guidance principle and five rules.

\section{Acknowledgement}

I would like to thanks to Mr. Muhammad Tresnadi Hikmat as my advisor who gave me best suggestions and business insight to complete this paper. Also to my family, Muhammad Azi Nugraha, Agam, Mega Kartika, Hana, Mega Permata, Bakti, Robi, Adriati, Niar, and Safira who always support and cheer me up.

\section{References}

[1] Aguinis H, Performance Management, $3^{\text {rd }}$ ed, Upper Saddle, New Jersey: Prentice Hall, (2013), pp: 2

[2] Afiani W, \& Madiawati PN, "Influence of Brand Image and Service Quality on Customer Loyalti on Users of Shipping Service PT. Pos Indonesia (Persero) Bandung Head Office", E-Proceeding of Management. Vol.2, No.3, (2015), pp:3721-3725, http://openlibrary.telkomuniversity.ac.id

[3] Anna A, "Strategic Management Tools and Techniques and Organizational Performance: Findings from the Czech Republic", Journal of Competitiveness, Vol.7, No.3, (2015), pp:19-36.

[4] Asosiasi Penyelenggara Jasa Internet Indonesia (APJII), Penetrasi \& Perilaku Pengguna Internet Indonesia, (2016)

[5] Bititci US, Carrie AS, \& McDevitt, "Integrated Performance Measurment Systems: a Development Guide", International of Journal of Operations \& Production Management, Vol. 17, No.5, L (1997), pp:522-534.

[6] Bititci US, Mendibil K, Nudurupati, Garengo, Turner T, "Dynamics of Performance Measurement and Organizational Culture", International Journal of Operations \& Production Management, Vol.26, No.12, (2006), pp:1325-1350.

[7] Dalimunthe A, PT Pos Indonesia Lakukan Brand Rejuvenation Untuk Rebut Pasar Paket, available online: www.Industry.co.id, last visit:14.6.2017

[8] Das K, Gryseels M, Sudhir P, \& Tan KT, Unlocking Indonesia's Digital Opportunity, McKinsey Company, (2016), pp:7-23.

[9] Hartung A, Why the Postal Service Is Going Out of Business, Available online: https://www.forbes.com, last visit:6.12.2011

[10] Hitt MA, Ireland RD, \& Hoskisson R, Strategic Management: Competitiveness and Globalization, $8^{\text {th }} \mathrm{ed}$, Mason, US: America South-Western CENGAGE Learning, (2009), pp:35-121.

[11] Hikmat MT, Primiana I, \& Wibisono D, "Analyzing Mainstreams In Current Performance Management Studies And Its Relationship With HR And Other Practices: A Literature Review", Sains Humanika (UTM, Malaysia), Vol.8, No.1-2, (2016), pp:41-50.

[12] International Post Corporation, Global Postal Industry Report Key Finding, (2015).

[13] Isoraite M, "Theoretical Aspects of Benchmarking Theory", Viesoji Politika IR Administravimas, No.9, (2004), pp: 21-26.

[14] Jacobs FR, \& Chase RB, Operation and Supply Chain Management $14^{\text {th }}$ ed, New York: McGraw Hill Education, (2011).

[15] Kaplan RS, \& Norton DP, Alignment: Using the Balanced Scorecard to Create Corporate Synergies. United States: Harvard Business School Press. (2008).

[16] Niven PR, Balanced Scorecard Step By Step - Maximizing Performance and Maintaining Results, $2^{\text {nd }}$ Ed, New Jersey: Wiley, (2006).

[17] Pearce, JA, "The Company Mission as a Strategic Tool", Sloan Managemet Review, Vol.23, No.3, (1982), pp:15.

[18] Razdan R, Das M, \& Sohoni A, The Evolving Indonesian Consumer. Asias Consumer Insight Center, McKinsey Company, (2013).

[19] Soo KG, "Building Your Company with Strong Vision Platform", Advanced Technologies \& Aerospace Database, Vol.17, No.7, (2017), pp:3021-3026.

[20] Smither JW, \& London M, Performance Management: Putting Research into Action, 1st ed, San Fransisco: Jossey Bass, (2009), pp:272.

[21] Wibisono D, How To Create A World Class Company: Panduan Bagi Direktur dan Manajer, Bandung: ITB, (2016). 
[22] Wheelen TL , \& Hunger DJ, Strategic Management and Business Policy Toward Global Sustainability, $13^{\text {th }}$ ed, New Jersey: Pearson Education Inc, (2012).

Exhibit 1: Value chain analysis

\begin{tabular}{|c|c|c|c|c|}
\hline \multirow{2}{*}{\multicolumn{5}{|c|}{ Firm Infrastructure }} \\
\hline & & & & \\
\hline \multicolumn{5}{|l|}{ 2. Has a full government support. } \\
\hline \multicolumn{5}{|c|}{ 3. Has good financial resource. } \\
\hline 4. Lack of performance manager & nent system & & & \\
\hline \multirow{2}{*}{\multicolumn{5}{|c|}{$\begin{array}{l}\text { Human Resource Management } \\
\text { 1. Conduct training once a month to improve employee competence (in house training, workshops, an }\end{array}$}} \\
\hline & & & & \\
\hline \multicolumn{5}{|c|}{ 2. Conduct sharing session once a month to increase employee knowledge management } \\
\hline \multicolumn{5}{|c|}{ 3. Has a big proportion of employee over 50 years old. $\quad$ Technology Development } \\
\hline \multirow{2}{*}{\multicolumn{5}{|c|}{$\begin{array}{l}\text { 1. Has a special department for IT development. } \\
\text { 2. Late in technology development process. }\end{array}$}} \\
\hline & & & & \\
\hline \multicolumn{5}{|c|}{$\begin{array}{l}\text { 2. Late in technology development process. } \\
\text { 3. The technology has not been able to meet market conditions. }\end{array}$} \\
\hline \multicolumn{5}{|c|}{ Procurement } \\
\hline \multicolumn{5}{|c|}{$\begin{array}{l}\text { 1. The procurement process of goods and services is conducted in accordance with government regulation Number } 15 / \mathrm{MBU} / 2012 \text { on general guidelines on the } \\
\text { procurement of goods and services. }\end{array}$} \\
\hline Inbound Logistic & Operations & Outbound Logistics & Marketing and Sales & After-Sales Service \\
\hline $\begin{array}{l}\text { 1. Using systems that designed } \\
\text { to facilitate planning, scheduling, } \\
\text { and determining distribution } \\
\text { patterns. } \\
\text { 2. Has widespread distribution } \\
\text { center within Indonesia } \\
\text { 3. Cooperate with Poslogistik, } \\
\text { PT KAI, PT Garuda Indonesia, } \\
\text { PT Len, PT Pelni, and various } \\
\text { companies engaged in the field } \\
\text { of transportation to support } \\
\text { goods delivery activities. }\end{array}$ & $\begin{array}{l}\text { 1. Using barcode system. } \\
\text { 2. Manual sorting process. } \\
\text { 3. The business process still wait } \\
\text { for the customer to come to Pos } \\
\text { Outlet directly. }\end{array}$ & $\begin{array}{l}\text { 1. Distribution centers are } \\
\text { widespread within Indonesia. } \\
\text { 2. Has many shipping routes. } \\
\text { 3. Delivery schedule depend on } \\
\text { supplier(transportation } \\
\text { company). }\end{array}$ & $\begin{array}{l}\text { 1. Cooperate with various e- } \\
\text { commerce in Indonesia. } \\
\text { 2. Price based on actual weight. } \\
\text { 3. Relatively offer cheaper price } \\
\text { than competitors. } \\
\text { 4. Lack of brand image. } \\
\text { 5. Promotion and advertising. }\end{array}$ & $\begin{array}{l}\text { 1. Track and trace fitur on } \\
\text { website and smartphone } \\
\text { application. } \\
\text { 2. Customer care service. } \\
\text { 3. Online customer complain. } \\
\text { 3. Customer gathering. }\end{array}$ \\
\hline
\end{tabular}

Exhibit 2: Four criteria for sustainable competitive advantage of Pos Indonesia

\begin{tabular}{|c|c|c|c|c|c|}
\hline & Valuable & Rare & Costly & Non-substitutable & $\begin{array}{c}\text { Competitive Conse- } \\
\text { quences } \\
\end{array}$ \\
\hline $\begin{array}{l}\text { 1. Has fully government support to be the e- } \\
\text { commerce platform of the national logistics } \\
\text { sector. }\end{array}$ & $\sqrt{ }$ & $\sqrt{ }$ & $\sqrt{ }$ & $\sqrt{ }$ & $\begin{array}{l}\text { Sustainable Competitive } \\
\text { Advantage }\end{array}$ \\
\hline $\begin{array}{l}\text { 2. Has a vast network to reach all area of the } \\
\text { country including rural area. }\end{array}$ & $\sqrt{ }$ & & $\sqrt{ }$ & & Competitive Parity \\
\hline $\begin{array}{l}\text { 3. Cooperate with various transportation compa- } \\
\text { nies to support the delivery activities. }\end{array}$ & $\sqrt{ }$ & & & & Competitive Parity \\
\hline $\begin{array}{l}\text { 4. Cooperate with various e-commerce compa- } \\
\text { nies in Indonesia. }\end{array}$ & $\sqrt{ }$ & & & & Competitive Parity \\
\hline 5. Has many delivery routes. & $\sqrt{ }$ & & & & Competitive Parity \\
\hline $\begin{array}{l}\text { 6. Provide cheapest price for standard delivery } \\
\text { service by using price based on actual weight } \\
\text { (no rounding weight) strategy }\end{array}$ & $\sqrt{ }$ & $\sqrt{ }$ & $\sqrt{ }$ & $\sqrt{ }$ & $\begin{array}{l}\text { Sustainable Competitive } \\
\text { Advantage }\end{array}$ \\
\hline
\end{tabular}

Exhibit 3: SWOT TOWS analysis

\begin{tabular}{|c|c|c|}
\hline $\begin{array}{l}\text { External } \\
\text { Factors }\end{array}$ & $\begin{array}{l}\text { Strengths } \\
\text { 1. Has fully government support to be the e- } \\
\text { commerce platform of the national logistics } \\
\text { sector. } \\
\text { 2. Provide cheapest price for standard deliv- } \\
\text { ery service by using price based on actual } \\
\text { weight (no rounding weight) strategy }\end{array}$ & $\begin{array}{l}\text { Weaknesses } \\
\text { 1. Lack of technology. } \\
\text { 2. Delivery process depends on the transpor- } \\
\text { tation company. } \\
\text { 3. Lack of brand image and service quality. } \\
\text { 4. Lack of product innovation. } \\
\text { 5. Lack performance management system. }\end{array}$ \\
\hline $\begin{array}{l}\text { Opportunities } \\
\text { 1. The Economy Policy Package XIV about } \\
\text { e-commerce road map. } \\
\text { 2. Population consumption is increase as } \\
\text { well as the growth of investment or sav- } \\
\text { ings. } \\
\text { 3. Consumer purchasing power is predicted } \\
\text { to increase. } \\
\text { 4. The e-commerce industry is predicted to } \\
\text { increase. } \\
\text { 5. Indonesia's logistics industry is predicted } \\
\text { to increase by } 15.4 \% \text { or Rp } 4.396 \text { trillion } \\
\text { in } 2020 \text {. } \\
\text { 6. There is no substitute product in terms of } \\
\text { parcel delivery service. }\end{array}$ & $\begin{array}{l}\mathrm{S}(1)(2)-\mathrm{W}(1)(2)(3)(4)(5)(6) \\
\text { Expand market to increase the number of } \\
\text { network within Indonesia. } \\
\text { Develop synergy with e-commerce and } \\
\text { transportation company. }\end{array}$ & $\begin{array}{l}\mathrm{W}(1)-\mathrm{O}(1)(4) \\
\text { Improve technology to support its business. } \\
\mathrm{W}(2)-\mathrm{O}(1)(4)(5) \\
\text { Acquire and develop synergy with the trans- } \\
\text { portation company. } \\
\text { W(1)(3)-O(1)(4) } \\
\text { Increase service quality through increase de- } \\
\text { livery service, reduce customer complain, and } \\
\text { improve the track and trace feature. }\end{array}$ \\
\hline
\end{tabular}




\begin{tabular}{|c|c|c|}
\hline & & $\begin{array}{l}\mathrm{W}(4)-\mathrm{O}(2)(3)(5) \\
\text { Develop new product and improve the existing } \\
\text { product. }\end{array}$ \\
\hline $\begin{array}{l}\text { Threats } \\
\text { 1. The change in UU No. } 38 / 2009 \text { makes } \\
\text { the competition in courier and logistic } \\
\text { industry getting tighter. } \\
\text { 2. High bargaining power of customer. } \\
\text { 3. Price sensitivity of customer is high. } \\
\text { 4. The existence of product innovation } \\
\text { offered by competitors. } \\
\text { 5. The trend of digitalization changes the } \\
\text { customer lifestyle. }\end{array}$ & $\begin{array}{l}\mathrm{S}(1)(2)-\mathrm{T}(1)(2) \\
\text { Maintain and expand its network and delivery } \\
\text { routes. } \\
\mathrm{S}(1)-\mathrm{T}(4)(5) \\
\text { Develop new product and improve the existing } \\
\text { product. } \\
\mathrm{S}(3)-\mathrm{T}(3) \\
\text { Maintain its operational expense and COGS in } \\
\text { order to provide cheaper price. }\end{array}$ & $\begin{array}{l}\text { W(1)(4)-T(1)(4)(5) } \\
\text { Develop robust technology to support the } \\
\text { business process. Such as improve existing } \\
\text { product and develop new product with digital } \\
\text { base. } \\
\mathrm{W}(2)(3)-\mathrm{T}(1)(2)(3) \\
\text { Improve operational activity and delivery } \\
\text { system to give best service quality. } \\
\mathrm{W}(5)-\mathrm{T}(1) \\
\text { Improve its performance management system. }\end{array}$ \\
\hline
\end{tabular}

Exhibit 4: KPI of organizational output

\begin{tabular}{|c|c|c|c|c|c|c|c|c|c|c|}
\hline Perspective & Variable & Objective & \multicolumn{2}{|c|}{ Indicator (KPI) } & Formula & Unit & Target & Polarity & Period & Status \\
\hline \multirow[t]{7}{*}{$\begin{array}{l}\text { Organization- } \\
\text { al Output }\end{array}$} & \multirow[t]{5}{*}{$\begin{array}{c}\text { Financial } \\
\text { Output }\end{array}$} & \multirow[t]{2}{*}{$\begin{array}{l}\text { To increase the } \\
\text { profitability }\end{array}$} & \multicolumn{2}{|c|}{ Profit Growth } & $\begin{array}{l}\text { (Current profit-Previous } \\
\text { Profit Previous Profit) x } \\
100 \%\end{array}$ & $\%$ & $\begin{array}{c}\text { Increase } \\
25\end{array}$ & $\begin{array}{l}\text { The higher } \\
\text { the better }\end{array}$ & Annually & New \\
\hline & & & \multicolumn{2}{|c|}{ EBITDA Margin } & $\begin{array}{l}\text { (EBITDA/Total } \\
\text { Revenue) } \times 100 \%\end{array}$ & $\%$ & $\begin{array}{c}\text { increase } \\
24.2\end{array}$ & $\begin{array}{l}\text { The higher } \\
\text { the better }\end{array}$ & Annually & Improved \\
\hline & & $\begin{array}{l}\text { To increase the } \\
\text { assets }\end{array}$ & \multicolumn{2}{|l|}{ Asset Growth } & $\begin{array}{l}\text { (Current Assets-Previous } \\
\text { Assets /Previous Assets) } \\
\text { x } 100 \%\end{array}$ & $\%$ & $\begin{array}{c}\text { increase } \\
9.41\end{array}$ & $\begin{array}{l}\text { The higher } \\
\text { the better }\end{array}$ & Annually & Improved \\
\hline & & $\begin{array}{l}\text { To evaluate the } \\
\text { ability of the } \\
\text { company to } \\
\text { generate sales } \\
\text { by its assets }\end{array}$ & \multicolumn{2}{|c|}{ Asset Turnover } & Sales/Total Asset & Times & 1.25 & $\begin{array}{l}\text { The higher } \\
\text { the better }\end{array}$ & Annually & New \\
\hline & & $\begin{array}{l}\text { To increase the } \\
\text { market share }\end{array}$ & \multicolumn{2}{|l|}{ Market Share } & $\begin{array}{l}\text { Company's } \\
\text { Revenue/ndustry } \\
\text { Revenue }\end{array}$ & $\%$ & 30 & $\begin{array}{l}\text { The higher } \\
\text { the better }\end{array}$ & Annually & Improved \\
\hline & \multirow[t]{2}{*}{$\begin{array}{c}\text { Non- } \\
\text { Financial } \\
\text { Output }\end{array}$} & \multirow[t]{2}{*}{$\begin{array}{l}\text { To increase the } \\
\text { customer } \\
\text { satisfaction }\end{array}$} & \multirow{2}{*}{$\begin{array}{l}\text { Customer } \\
\text { Satisfaction }\end{array}$} & $\begin{array}{l}\text { Corporate } \\
\text { Customer } \\
\text { Satisfaction }\end{array}$ & $\begin{array}{l}\text { Number of } \\
\text { complaint Target } \\
\text { complain }\end{array}$ & $\%$ & 85 & $\begin{array}{l}\text { The lower the } \\
\text { better }\end{array}$ & Annually & New \\
\hline & & & & $\begin{array}{l}\text { Individual } \\
\text { Customer } \\
\text { Satisfaction }\end{array}$ & $\begin{array}{l}\text { Number of } \\
\text { complaint Target } \\
\text { complain }\end{array}$ & $\%$ & 85 & $\begin{array}{l}\text { The lower the } \\
\text { better }\end{array}$ & Annually & New \\
\hline
\end{tabular}

Exhibit 5: KPI of internal process

\begin{tabular}{|c|c|c|c|c|c|c|c|c|c|}
\hline Perspective & Variable & Objective & Indicator (KPI) & Formula & Unit & Target & Polarity & Period & Status \\
\hline \multirow[t]{7}{*}{$\begin{array}{l}\text { Internal } \\
\text { Process }\end{array}$} & \multirow[t]{2}{*}{ Innovation } & $\begin{array}{l}\text { To evaluate the } \\
\text { investment project } \\
\text { that has been } \\
\text { conducted }\end{array}$ & $\begin{array}{l}\text { WorkProgram } \\
\text { Realization }\end{array}$ & $\begin{array}{l}\text { Investment plan } \\
\text { program/Planned } \\
\text { program }\end{array}$ & $\%$ & 95 & $\begin{array}{l}\text { The higher the } \\
\text { better }\end{array}$ & Quarterly & Improved \\
\hline & & $\begin{array}{l}\text { To evaluate } \\
\text { investment asset that } \\
\text { used for the project }\end{array}$ & $\begin{array}{l}\text { Physical Program } \\
\text { Realization }\end{array}$ & $\begin{array}{l}\text { Realization of } \\
\text { investment plan budget } \\
\text { imvestment plan budget }\end{array}$ & $\%$ & 95 & $\begin{array}{l}\text { The higher the } \\
\text { better }\end{array}$ & Quarterly & Improved \\
\hline & \multirow[t]{2}{*}{$\begin{array}{l}\text { Operating } \\
\text { Process }\end{array}$} & $\begin{array}{l}\text { To control the } \\
\text { operating cost }\end{array}$ & Operating Ratio & Operating cost Revenue & $\%$ & 75.8 & $\begin{array}{l}\text { The lower the } \\
\text { better }\end{array}$ & Quarterly & New \\
\hline & & $\begin{array}{l}\text { To evaluate } \\
\text { reliability of the } \\
\text { service provided }\end{array}$ & $\begin{array}{l}\text { Standard Delivery } \\
\text { Time }\end{array}$ & $\begin{array}{l}\text { Average delivery } \\
\text { time Target }\end{array}$ & Days & 2 & $\begin{array}{l}\text { The lower the } \\
\text { better }\end{array}$ & Quarterly & New \\
\hline & \multirow[t]{2}{*}{ Marketing } & $\begin{array}{l}\text { To increase the e- } \\
\text { commerce market } \\
\text { share }\end{array}$ & $\begin{array}{l}\text { E-Commerce } \\
\text { Penetration }\end{array}$ & $\begin{array}{l}\text { (Total number of current } \\
\text { e-commerce customer - } \\
\text { total number of previous } \\
\text { e-commerce } \\
\text { customer) total number } \\
\text { of previous e-commerce } \\
\text { customer }\end{array}$ & $\%$ & $\begin{array}{c}\text { increase } \\
15\end{array}$ & $\begin{array}{l}\text { The higher the } \\
\text { better }\end{array}$ & Annually & New \\
\hline & & $\begin{array}{l}\text { To increase the } \\
\text { number of network }\end{array}$ & Network growth & $\begin{array}{l}\text { Total number of current } \\
\text { network - total number } \\
\text { of previous } \\
\text { network) total number of } \\
\text { previous network }\end{array}$ & $\%$ & $\begin{array}{c}\text { increase } \\
10\end{array}$ & $\begin{array}{l}\text { The higher the } \\
\text { better }\end{array}$ & Annually & New \\
\hline & $\begin{array}{l}\text { After Sales } \\
\text { Service }\end{array}$ & $\begin{array}{l}\text { To evaluate the } \\
\text { ability of the } \\
\text { company to solve the } \\
\text { customer problem } \\
\text { associated with the } \\
\text { service provided }\end{array}$ & $\begin{array}{l}\text { Respond Time to } \\
\text { Complain Handling }\end{array}$ & $\begin{array}{l}\text { The number of working } \\
\text { days required to } \\
\text { complete a customer } \\
\text { complaint }\end{array}$ & $\begin{array}{l}\text { Work } \\
\text { ing } \\
\text { Days }\end{array}$ & 2 & $\begin{array}{l}\text { The lower the } \\
\text { better }\end{array}$ & Quarterly & Improved \\
\hline
\end{tabular}


Exhibit 6: KPI of resources availability

\begin{tabular}{|c|c|c|c|c|c|c|c|c|c|}
\hline \multirow{7}{*}{$\begin{array}{l}\text { Perspective } \\
\text { Resource } \\
\text { Availability }\end{array}$} & Variable & Objective & Indicator (KPI) & Formula & Unit & Target & Polarity & Period & Status \\
\hline & \multirow[t]{3}{*}{$\begin{array}{l}\text { Human } \\
\text { Resource }\end{array}$} & $\begin{array}{l}\text { To increase the } \\
\text { employee } \\
\text { engagement }\end{array}$ & $\begin{array}{l}\text { Employee } \\
\text { Engagement Index }\end{array}$ & $\begin{array}{l}\text { Survey result target } \\
\text { engagement }\end{array}$ & $\%$ & 90 & $\begin{array}{l}\text { The higher the } \\
\text { better }\end{array}$ & Annually & Improved \\
\hline & & $\begin{array}{l}\text { To increase the } \\
\text { employee } \\
\text { productivity }\end{array}$ & $\begin{array}{l}\text { Employee } \\
\text { Productivity }\end{array}$ & $\begin{array}{l}\text { Revenue total number of } \\
\text { employee }\end{array}$ & $\begin{array}{l}\text { Million } \\
\text { Rupiah } E \\
\text { mployee }\end{array}$ & $\begin{array}{l}\text { increas } \\
\text { e } 25 \%\end{array}$ & $\begin{array}{l}\text { The higher the } \\
\text { better }\end{array}$ & Quarterly & Improved \\
\hline & & $\begin{array}{l}\text { To increase the } \\
\text { employee } \\
\text { satisfaction level }\end{array}$ & $\begin{array}{l}\text { Employee } \\
\text { Satisfaction }\end{array}$ & $\begin{array}{l}\text { Survey of employee } \\
\text { satisfaction }\end{array}$ & $\%$ & 90 & $\begin{array}{l}\text { The higher the } \\
\text { better }\end{array}$ & Annually & New \\
\hline & Technology & $\begin{array}{l}\text { To evaluate the } \\
\text { readiness and } \\
\text { reliability of } \\
\text { corporate } \\
\text { networks } \\
\text { technology }\end{array}$ & $\begin{array}{l}\text { Network Technology } \\
\text { A vailability }\end{array}$ & $\begin{array}{l}\text { Avaliabilitites } \\
\text { Realizations/Target } \\
\text { availabilities }\end{array}$ & $\%$ & 99.5 & $\begin{array}{l}\text { The higher the } \\
\text { better }\end{array}$ & Annually & New \\
\hline & \multirow[t]{2}{*}{$\begin{array}{l}\text { Organizational } \\
\text { Resource }\end{array}$} & $\begin{array}{l}\text { To evaluate the } \\
\text { implementation } \\
\text { of } G C G \text { C }\end{array}$ & GCG Index & $\begin{array}{l}\text { GCG Realization Target } \\
\text { of GCG }\end{array}$ & $\%$ & 86 & $\begin{array}{l}\text { The higher the } \\
\text { better }\end{array}$ & Annually & Improved \\
\hline & & $\begin{array}{l}\text { To evaluate the } \\
\text { PSO } \\
\text { implementation }\end{array}$ & PSO Implementation & $\begin{array}{l}\text { Investment } \\
\text { cost Government fund }\end{array}$ & $\%$ & 100 & $\begin{array}{l}\text { The higher the } \\
\text { better }\end{array}$ & Annually & Improved \\
\hline
\end{tabular}

Exhibit 7: Linkage variable

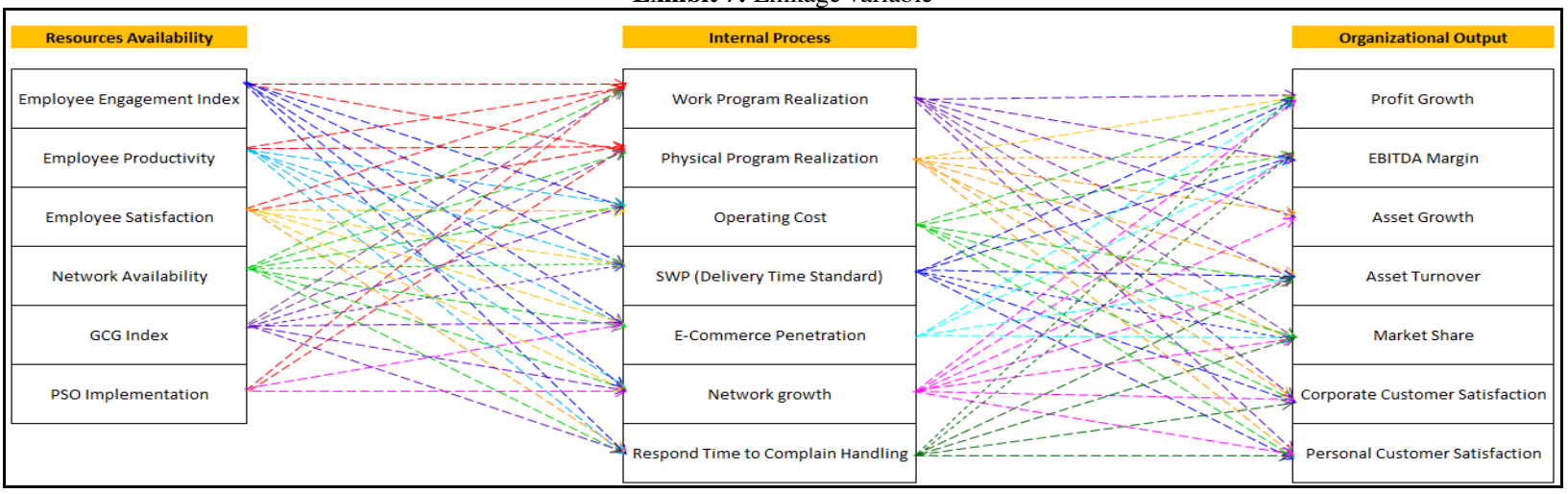

Exhibit 8: Benchmark

\begin{tabular}{|c|c|c|c|c|c|c|c|c|c|c|c|c|c|}
\hline \multirow{2}{*}{\multicolumn{2}{|c|}{$\begin{array}{l}\text { Company } \\
\text { Type of Delivery Service }\end{array}$}} & \multicolumn{6}{|c|}{ Pos Indonesia } & \multicolumn{6}{|c|}{ JNE } \\
\hline & & \multirow{2}{*}{\multicolumn{2}{|c|}{$\begin{array}{l}\text { Standard Parcel } \\
\text { Parcels delivery } \\
\text { service at the } \\
\text { most economical } \\
\text { rates. }\end{array}$}} & \multirow{2}{*}{\multicolumn{2}{|c|}{$\begin{array}{l}\text { Special Express } \\
\text { Parcel } \\
\text { Service for safe } \\
\text { and fast delivery } \\
\text { with wide reach to } \\
\text { all parts of } \\
\text { Indonesia. }\end{array}$}} & \multicolumn{2}{|c|}{ Express Next Day } & \multicolumn{2}{|c|}{$\mathrm{OKE}$} & \multicolumn{2}{|l|}{ REG } & \multicolumn{2}{|c|}{ YES } \\
\hline \multicolumn{2}{|l|}{ Description } & & & & & \multicolumn{2}{|c|}{\begin{tabular}{|l|} 
Pos Indonesia's \\
premium services \\
for fast and secure \\
delivery with \\
wide coverage to \\
all parts of \\
Indonesia.
\end{tabular}} & \multicolumn{2}{|c|}{$\begin{array}{l}\text { Delivery service } \\
\text { for large or } \\
\text { heavy items at an } \\
\text { economical } \\
\text { price. }\end{array}$} & \multicolumn{2}{|c|}{$\begin{array}{l}\text { Fast delivery } \\
\text { service, safe, and } \\
\text { reliable to the } \\
\text { comers of } \\
\text { Indonesia. }\end{array}$} & \multicolumn{2}{|c|}{$\begin{array}{l}\text { Premium delivery } \\
\text { service with the } \\
\text { target of shipment } \\
\text { to destination on } \\
\text { the next day } \\
\text { including on } \\
\text { Sunday and } \\
\text { national holiday. }\end{array}$} \\
\hline Destination & $\begin{array}{l}\text { Weight } \\
(\mathrm{Kg})\end{array}$ & Price & Days & Price & Days & Price & Days & Price & Days & Price & Days & Price & Days \\
\hline \multirow{3}{*}{$\begin{array}{l}\text { Bandung - } \\
\text { Semarang }\end{array}$} & 1 & 6.901 & \multirow{15}{*}{$\begin{array}{l}7- \\
14\end{array}$} & 16.160 & \multirow{3}{*}{2} & 22.220 & \multirow{12}{*}{1} & 12.000 & \multirow{6}{*}{$2-3$} & \multirow{2}{*}{$\begin{array}{l}14.000 \\
42.000\end{array}$} & \multirow{15}{*}{$1-2$} & \multirow{2}{*}{$\begin{array}{l}17.000 \\
51.000\end{array}$} & \multirow{12}{*}{1} \\
\hline & 2.5 & 20.704 & & 48.480 & & 66.660 & & 36.000 & & & & & \\
\hline & 5 & 28.784 & & 80.800 & & 111.100 & & 60.000 & & 70.000 & & 85.000 & \\
\hline \multirow{3}{*}{$\begin{array}{c}\text { Bandung - } \\
\text { Pangkal Pinang } \\
\text { (Bengkulu) }\end{array}$} & 1 & 9.090 & & 23.735 & & 29.795 & & 22.000 & & 25.000 & & 30.000 & \\
\hline & 2.5 & 27.270 & & 71.204 & & 89.384 & & 66.000 & & 75.555 & & 90.000 & \\
\hline & 5 & 39.390 & & 118.673 & & 148.973 & & 110.000 & & 125.000 & & 150.000 & \\
\hline Bandung - & 1 & 12.120 & & 28.280 & & 36.360 & & 24.000 & & 28.000 & & 36.000 & \\
\hline Pontianak (West & 2.5 & 36.360 & & 84.840 & & 109.080 & & 72.000 & & 84.000 & & 108.000 & \\
\hline Kalimantan) & 5 & 55.650 & & 141.400 & & 181.800 & & 120.000 & & 140.000 & & 180.000 & \\
\hline Bandung - & 1 & 16.160 & & 26.260 & $2-4$ & 37.370 & & 23.000 & & 26.000 & & 37.000 & \\
\hline Makassar (South & 2.5 & 48.480 & & 78.780 & & 112.110 & & 69.000 & & 78.000 & & 111.000 & \\
\hline Sulawesi) & 5 & 74.740 & & 131.300 & & 186.850 & & 115.000 & & 130.000 & & 185.000 & \\
\hline Bandung - & 1 & 29.795 & & 71.205 & & & & 66.000 & & 77.000 & & & \\
\hline North Jayapura & 2.5 & 89.384 & & 213.614 & & - & - & 198.000 & & 231.000 & & - & - \\
\hline & 5 & 131.804 & & 356.023 & & & & 330.000 & & 385.000 & & & \\
\hline
\end{tabular}


Exhibit 9: Supporting documents and resource allocation

\begin{tabular}{|c|c|c|c|}
\hline Category & Document & Availability & PIC \\
\hline \multirow{3}{*}{ Financial } & Balance Sheet & Available & Financial management and Accounting \\
\hline & Income Statement & Available & Financial management and Accounting \\
\hline & Investment financial Report & Available & Treasure and Tax \\
\hline \multirow[t]{10}{*}{ Administrative Data } & Customer complaint report & Available & $\begin{array}{l}\text { Outlet Division, Mail Business Development Division, } \\
\text { Parcel Business Development Division, Business De- } \\
\text { velopment And Financial Services Division }\end{array}$ \\
\hline & Physical program realization report & Available & Treasure and Tax \\
\hline & PSO Implementation Report & Available & Public Service Obligation \\
\hline & Market Share Report & Available & $\begin{array}{l}\text { Mail Business Development Division, Parcel Business } \\
\text { Development Division, Business Development And } \\
\text { Financial Services Division }\end{array}$ \\
\hline & Delivery time report & Available & Operating Control System Division \\
\hline & Complaints Settlement Report & Available & Customer Complain Division \\
\hline & E-commerce customer report & Available & $\begin{array}{l}\text { Mail Business Development Division, Parcel Business } \\
\text { Development Division, Business Development And } \\
\text { Financial Services Division }\end{array}$ \\
\hline & Number of Network Report & Available & Outlet Division \\
\hline & Network Technology Availability Report & Available & Information Technology \\
\hline & GCG Audit Report & Available & GCG and Risk Management \\
\hline \multirow[t]{2}{*}{ Human Resource Data } & $\begin{array}{l}\text { Employee engagement and satisfaction } \\
\text { survey report }\end{array}$ & Available & $\begin{array}{l}\text { PPTP (Pusat Perencanaan dan Transformasi Perus- } \\
\text { ahaan) }\end{array}$ \\
\hline & Employee Productivity Report & Available & Financial, Accounting, SDM \\
\hline
\end{tabular}

Exhibit 10: Comparison before and after ipms using four guidance principles

\begin{tabular}{|l|l|l|}
\multicolumn{1}{|c|}{ Exhibit 10: Comparison before and after ipms using four guidance principles } \\
\hline Four Principles & \multicolumn{1}{|c|}{ Before IPMS } & \multicolumn{1}{c|}{ After IPMS } \\
\hline Partnership & $\begin{array}{l}\text { There is no understanding among the company stakeholders } \\
\text { of the need for a thorough change due to the implementa- } \\
\text { tion of a new system of performance management designed. }\end{array}$ & $\begin{array}{l}\text { By using IPMS all the stakeholder can participate to imple- } \\
\text { ment the new performance management system. }\end{array}$ \\
\hline Empowerment & $\begin{array}{l}\text { The roles and responsibility of the area in the company is } \\
\text { stand alone and has a lack improvement. }\end{array}$ & $\begin{array}{l}\text { Since IPMS provides the variable linkage that make a clear } \\
\text { causal relationship between the KPI, it can help the compa- } \\
\text { ny to make a continuous improvement which is can be con- } \\
\text { ducted by all level of employee. }\end{array}$ \\
\hline $\begin{array}{l}\text { Integrated Performance } \\
\text { Improvement }\end{array}$ & $\begin{array}{l}\text { Pos Indonesia uses three performance variables which has a } \\
\text { different function and not integrated between each other. }\end{array}$ & $\begin{array}{l}\text { There is an alignment in the IPMS framework between } \\
\text { company's vision, mission, strategy, until the lower level } \\
\text { management of the company, so it provide the integrated } \\
\text { performance management. }\end{array}$ \\
\hline Independent & $\begin{array}{l}\text { There is an independent team that created to develop the } \\
\text { performance management system in the company, but not } \\
\text { synergize with other departments. }\end{array}$ & $\begin{array}{l}\text { There will be a synergy between the team that already estab- } \\
\text { lished with all management area of the company. }\end{array}$ \\
\hline
\end{tabular}

Exhibit 11: Comparison before and after ipms using five rules

\begin{tabular}{|c|l|}
\hline Five Rules & \multicolumn{1}{|c|}{ Before IPMS } \\
\hline Easy to Understand & $\begin{array}{l}\text { Before using IPMS the performance management system that } \\
\text { implemented by the company is difficult to understand because } \\
\text { they using three different framework that makes an overlap } \\
\text { implemented performance management system. }\end{array}$ \\
\hline Long Term Orientation & $\begin{array}{l}\text { Before using IPMS the performance management system that } \\
\text { implemented only provides the short-term orientation because } \\
\text { the company cannot predict the leading and lagging indicator } \\
\text { relationship. }\end{array}$ \\
\hline Time Based & $\begin{array}{l}\text { Before using IPMS the performance management system that } \\
\text { implemented is not following the trend of the market of any } \\
\text { changes that occur in the industry. }\end{array}$ \\
\hline Focus on Continuous & $\begin{array}{l}\text { Before using IPMS the performance management system that } \\
\text { implemented is not provide the continuous improvement. } \\
\text { Moreover, the KPKU only use to give the information to the } \\
\text { government without provides any feedback. }\end{array}$ \\
\hline Quantitative Approach & $\begin{array}{l}\text { BPIS, SMKU, and KPKU only provide a quantitative meas- } \\
\text { urement without providing the quantitative approach to evalu- } \\
\text { ate and determine root cause of the company's problem. }\end{array}$ \\
\hline
\end{tabular}

\section{After IPMS}

By using IPMS the company can only focus to one performance management system. So the implementation will be easier than before.

By using IPMS, the system is designed based on the vision and mission of the company strategy, the improvement process also divided into two aspects which is short and long-term orientation. So it provides the long term orientation.

By using IPMS there is a refreshment stage that make the performance management that used is always up to date.

By using IPMS there is four pillars as a set of activities that can lead the company to do a continuous improvement.

By using IPMS that equipped with the several data or reports, the company can determine the root cause of the problem occur with the quantitative approach such as regression, factor analysis, etc. 